\title{
COMPATIBILITY OF ISLAMIC FINANCE AND ANTI- MONEY LAUNDERING LAWS: A MYTH OR REALITY?
}

\author{
Maruf Adeniyi Nasir*
}

\begin{abstract}
Money Laundering (ML) remains a major threat to the financial flow, as well as affecting the economic stability of any nations. It is equally capable of undermining macroeconomic performance and therefore constitutes a very significant risk to both soundness and stability of any financial institution. Foreign direct investments are therefore adversely affected. Unlike that of the capitalist economy and other conventional banking institutions, the risks which ML poses to Islamic finance attracted little or no critical study. This could give the impression that Islamic finance is not in tune with Anti-Money Laundering Laws (AML) and the regulatory regime or that it is anti-AML. The resultant effect of this is unnecessary hostility to Islamic Financial products, which appears not to be in the interest of global economy. This article, therefore, focuses on the relevance of AML principles to Islamic banking. It is revealed that while no financial institution is immune to laundering, the risk-sharing nature of Islamic finances poses less systemic risk than conventional finance. It is recommended that FATF should facilitate studies of potential ML in Islamic finance to put the issue in the right perspective.
\end{abstract}

Keywords: money laundering; Islamic finance, shari‘ah

Lecturer at Department of Public and International Law, Osun State University, Osogbo, Nigeria, email: adeniyinasir@uniosun.edu.ng. 


\title{
KESERASIAN KEWANGAN ISLAM DAN UNDANG-UNDANG ANTI-PENGUBAHAN WANG HARAM: SATU MITOS ATAU REALITI?
}

\begin{abstract}
ABSTRAK
Pengubahan wang haram (AML) telah menjadi ancaman utama kepada aliran kewangan, kestabilan kewangan dan ekonomi setiap negara. Ia mampu melemahkan prestasi makroekonomi dan merupakan satu risiko yang sangat ketara untuk kemampanan dan kestabilan manamana institusi kewangan. Oleh itu, pelaburan langsung asing turut terjejas. Berbeza dengan ekonomi kapitalis dan institusi perbankan konvensional yang lain, terdapat sedikit mahupun tiada kajian kritikal berkenaan dengan risiko-risiko berkaitan dengan aktiviti penggubahan wang haram. Ini boleh memberi gambaran bahawa sistem kewangan Islam tidak selaras dengan Undang-undang Anti Penggubahan Wang Haram dan rejim pengawalseliaan atau bahawa ia adalah anti-AML. Akibatnya, permusuhan yang tidak wajar diada- adakan terhadap produk-produk Kewangan Islam, yang sebenarnya tidak menjadi kepentingan ekonomi global. Oleh itu, kertas kerja ini menumpukan kepada perkaitan prinsip AML kepada perbankan Islam. Kertas ini mendapati bahawa walaupun tiada institusi kewangan yang kebal daripada penggubahan wang haram, perkongsian risiko dalam kewangan Islam boleh menimbulkan risiko yang kurang sistematik berbanding sistem kewangan konvensional. Adalah disyorkan bahawa FATF harus memudahkan kajian berpotensi ML dalam kewangan Islam demi meletakkan isu tersebut dalam perspektif yang betul.
\end{abstract}

Kata kunci: penggubahan wang haram, kewangan Islam, syar 'iah 


\section{INTRODUCTION}

Money laundering is a phenomenon that constitutes a threat to the modern financial system. It is a complex global problem where launderers continue to perfect methods for cross borders movements of proceeds of crime. ${ }^{1}$ The havoc created by the menace of money laundering is enormous and remains unquantifiable in terms of actual estimates. Countries around the world have collaborated to address challenges posed by money laundering. In 1988, specialised standard bodies were established with the responsibility of setting specific standards for financial institutions to combat this crime. This was when the concept of money laundering was first officially coined and tabled at a United Nation Conference in Vienna, ${ }^{2}$ with the original intent of combatting the ever-growing problem of illicit drug-trafficking.

The threat which money laundering poses to the financial flow of every nation continues to attract the attention of several international forums, including the Vienna convention, the Basel Statement of Principles and the Council of Europe Convention on Laundering, leading to the creation of the Financial Action Task Force (FATF), an intergovernmental policy-making body which serves as a standard-setting organization that is set up to put in place a legal and regulatory framework for money laundering legislation. ${ }^{3}$ The forty 'Recommendations' of FATF's has become the standard regulatory framework for AML. All other legislations and regulations that are set up to combat money laundering and related offences are measured by FATF standards to assess their level of compliance.

The terrorist attack on the United States of America on September 11, 2001 has further contributed to the re-awakening of global concern on money laundering and terrorism financing. It has however of great concern that while the event has boosted the development and the growth of Anti-Money Laundering Laws and Combating Financing Terrorism

\footnotetext{
${ }^{1}$ Nasir, Maruf Adeniyi et al, "Money Laundering: A Paradox of Deterrence Mechanism" A paper presented at KLIBEL 11 'Business, Economics and Law Conference' on $17^{\text {th }}-18^{\text {th }}$ December, Putrajaya, Malaysia.

2 United Nations Convention against Illicit Traffic in Narcotic Drugs and Psychotropic Substances at Vienna (1988).

${ }^{3}$ Norhashimah, Mohd Yasin Legal Aspects of Money Laundering in Malaysia from the Common Law Perspective (Lexis Nexis, 2007).
} 
(AML/CFT), it seems to have equally created an apathy towards Islamic finance, fuelling a perception of a systemic bias and prejudice against anything Islamic. ${ }^{4}$

This attitude is reflected by linking; the Islamic financial services industry to money laundering and terrorism. Nevertheless, the perception that the Islamic financial services industry is more vulnerable or susceptible to money laundering and terrorism financing is without any empirical or legal basis.

Similarly, several accounts belonging to Islamic organisations, such as Zakat and Sadaqah institutions and individuals have been abruptly closed down in the United States without any explanation. ${ }^{5}$ While recently, in the United Kingdom, the HBSC closed down many Islamic charity accounts due to pressure from the US authorities. The accounts which belonged to 'Islamic Relief's' were alleged to pose money laundering risk. ${ }^{6}$

This article therefore examines the characteristics of Islamic finance with focus on Islamic banking institutions; taking cognisance of the core AML/CFT expected policies and procedures related to the following core areas; Identification of Customers, Record Keepings, Reporting Obligations, Account Monitoring as well as Regulatory Bodies Monitoring and Supervision, in order to assess the vulnerability of Islamic banking institutions to AML/CFT risks. This is done through doctrinal research method (i.e. a library-based research).

Accordingly, primary research materials were analysed from the forty 'Recommendations of the Financial Action Task Force (FATF), which depicts the acceptable legislative and regulatory precedent and international standard to measure the adequacy or otherwise of any national or local laws on AML/CFT. Secondary research materials such as textbooks and law journals containing articles by academic writers, seminar/workshop papers, newspaper/magazines and particularly the FATF's Mutual Evaluation Reports were also considered.

\footnotetext{
${ }^{4}$ Norhashimah Mohd Yasin, "Terrorism Financing Law in Malaysian," The Law Review, 2007, 100-117.

${ }^{5}$ RT Questionmore, "US Banks Suddenly Close Dozens of Accounts, Muslim Group Suspects Racial Profiling,” 2014, accessed December 25, 2016, https://www.rt.com/usa/.

${ }^{6}$ Aljazeerah, "HSBC Bank Cuts off Services to Muslim Charity," News, 2016, http://www.aljazeera.com/news/2016.
} 


\section{CONCEPTUAL ANALYSIS}

When the issue of organised crimes was raised, there are two concepts that are bound to dominate the discussion not only because of their own degree of notoriety, but also due to the negative effects that they have as driving forces for several other crimes. These two crimes are money laundering and terrorism financing. These two concepts have become interwoven, even though, they are not the same, but the former is seen as a main facilitator to the latter. ${ }^{7}$

While there is no consensus on the definition of terrorism financing, money laundering has attracted several definitions; the thrust of these ${ }^{8}$ definitions are that it is a process of disguising the original owner as well as proceeds of illegal activities to give an impression of a legitimate status. In the words of Reuter and Truman, ${ }^{9}$ "money laundering is the conversion of criminal incomes into assets that cannot be traced back to the underlying crimes". Due to its global nature, the regulatory framework for this menace falls within the realm of international bodies which have responded through several conventions stating from the Vienna Convention in 1988, Wolfsberg Principles in 2000, the Palermo Convention in 2001 and Merida Convention in 2005 among many others. ${ }^{10}$ Its process involves the placement, layering and integration of proceeds of crime.

Although terrorism does not have a uniform definition like that of money laundering, various international and local legal instruments have defined it in a closely related manner. Sections 1 and 2 of Terrorism Prevention Act 2011 in Nigeria covered a wide range of acts that constitute acts of terrorism and this is in tandem with the provisions of

${ }^{7}$ Maruf Adeniyi Nasir, "The Existing AML Legislations in Nigeria: Relevance to Islamic Banking Institutions.," in American Society of Comparative Law (ASCL) Younger Comparativists (YCC) (New Orleans: YCC, 2016).

${ }^{8}$ Money laundering.

9 Peter Reuter and Edwin M Truman, "Anti-Money Laundering Overkill?," International Economy 19, no. 1 (2005): 56-60.

${ }^{10}$ Lovell D Fernandez, "Corruption (Article 28I) and Money Laundering (Article 28Ibis)," in The African Criminal Court (Springer, 2017), 89-107. See also Lars Waldorf, "Anticipating the Past: Transitional Justice and SocioEconomic Wrongs,” Social \& Legal Studies, 2012. See also United Nations Conference of the Parties to the United Nations Convention against Transnational Organised Crime UN Doc CTOC7COP/2004/6 
the Malaysian section 130B of the Penal Code as well as Section 66A of Anti-Money Laundering, Anti-Terrorism Financing and Proceeds of Unlawful Activities Act (2013) (AMLATFPUAA). Terrorism is defined to include; any act done or threat made with the intention of advancing a political, religious or ideological cause; and an act or threat is intended or may reasonably be regarded as being intended to intimidate the public or a section of it; or influence or compel any government, whether in Malaysia or elsewhere, or any international organization to do or refrain from doing any act.

Terrorism Financing is therefore an act of raising funds, or other beneficial material used for terrorist acts. The funds in question may be from laundered money or criminal activities such as proceeds of crime or a legitimate funds from personal savings, profit from a legitimate business, gifts and donations from charitable organisations. ${ }^{11}$

\section{ISLAMIC FINANCE AND ANTI-MONEY LAUNDERING COMPLIANCE}

Islamic Finance refers to financial system that is based on the principles of Shariah. It is a Riba (Usury) free and its essential features includes; prohibitions of uncertainty (gharar), adoption of risk sharing, profit sharing, promotion of halal (permissible in Shariah), based in strong ethical precepts and being essentially asset-based. ${ }^{12}$

Under the principles of Islamic Finance, money cannot be traded due to lack of inherent value and all goods and services that are considered Haram (forbidden) cannot be traded as well. Thus, pornographic items, alcoholic substances, gambling, weapons of destructions, speculation, psychotropic substances, ${ }^{13}$ drugs and all other related products are among those that are forbidden under the principle of Shariah. ${ }^{14}$

${ }^{11}$ FINTRAC, "What Is Terrorist Financing?," accessed December 26, 2016, http://www.fintrac-canafe.gc.ca/.

${ }^{12}$ Faleel Jamaldeen, Islamic Finance for Dummies (John Wiley \& Sons, 2012).

${ }^{13}$ Hard drugs that ordinarily intoxicate or dangerous. They are generally classified as illegal and the consumption without prior approval from relevant authority is prohibited. Examples are Heroin, Cocaine, Marijuana and others

${ }^{14}$ Umar A. Oseni, "Dispute Management in Islamic Financial Services and Products: A Maqāṣid-Based Analysis," Intellectual Discourse 23 (2015). 
What distinguishes Islamic banking from other forms of banking is the nature of its financial intermediation that must be Shariah compliant. ${ }^{15}$ One of the major differences from other forms of banking therefore is the funding patterns. Islamic Bank is participatory finance as it is a non-interest fund and offers profit and loss-oriented financing. The investor in Islamic banks therefore takes his profit from the pool of assets or from the accrued profits in the profit-sharing investment accounts (PSIA).

Islamic banking remains relatively new compared to conventional banking but the rate of its growth is quite astonishing. Islamic banking institutions in the last few decades have witnessed an exponential growth within Islamic financial sector and the presence of Islamic banks has now spread to more than 50 countries of the world, in which they constitute more than $15 \%$ of the financial landscape. Islamic banking presently constitutes about $80 \%$ of the entire Islamic financial industry with estimated assets of more than US\$1.4 trillion globally and the number of Islamic banking institutions are presently over $400 .{ }^{16}$

There is now an increased feeling that has culminated into allegations, particularly in the western countries that Islamic Banking Institutions (IBI) are not only vulnerable but are serving as conduits for or linked in one way or the other to money laundering and terrorism financing. Consequently, attention has been consistently focussed on Islamic banking institution's (IBI) role in money laundering and terrorism financing. ${ }^{17}$

The regulatory and supervisory regime are alleged to be weak when compared to conventional banking institutions and compromised, giving room for its manipulation by the ever-sophisticated launderers. However, these are mere blanket allegations which appears to have been general in nature, based on this assumption, without necessarily being supported by evidence. ${ }^{18}$

15 Oseni, Umar "Dispute Management in Islamic Financial Services and Products: A Maqāșid-Based Analysis."

${ }^{16}$ Islamic Finance Services Board Stability Report cited in IMF Working Paper $\mathrm{WP} / 15 / \mathrm{XX}$

17 Norhashimah Mohd Yasin, Regulation of Islamic Banks and Allegations of Lax Control of Money La.undering, Journal of Islamic Law Review vol 4 (2008), pp 107-119.

${ }^{18}$ Ibid 
Based on the 9/11 terror attacks, the United States of America law enforcement agency has concluded that regulations of Islamic bank are lax. This generalised assertion does not exempt any Muslim country where Islamic banks exists. ${ }^{19}$ In a report released by US State Department, the following statements is made:

"Some terrorist groups may also use Islamic Banks to move funds. Islamic Banks operates within Islamic Law, which prohibit the payment of interest and certain activities. They are proliferated throughout Africa, Asia and Middle East since the mid-1970s. Some of the largest Islamic Financial institutions now operate investment houses in Europe and elsewhere. Many of these banks are not subject to a wide range of anti-money laundering regulations and controls normally imposed on secular commercial banks nor do they undergo the regulatory or supervisory scrutiny by bank regulators via periodic bank examinations or inspections. While these banks may voluntarily comply with banking regulations, and in particular, anti-money laundering guidelines, there is often no control mechanism to assure compliance or the implementation of updated anti-money laundering policies". ${ }^{20}$

The above allegation is weighty, and it appears to overly generalise non-compliance. There are countries that can be described as hub for Islamic banking and finance with a high record of compliance. A good example is Malaysia that has good records of implementing various antimoney laundering measures despite being one of the designated international centres for Islamic banking and finance. ${ }^{21}$

Incidentally, while many countries with only conventional banks are still found wanting in compliance with the international standard requirements on measures to combat money laundering and terrorism

19 Norhashimah Mohd Yasin, Malaysian Islamic Banking Regulation in Relation to Anti-Money Laundering and Counter Financing of Terrorism (AML/CFT): the Aftermath of Islamic Financial Services Act 2013 (IFSA). A Chapter in edited work of, Adnan Trakic and Hanifah Haydar Ali Tajuddin, Islamic Banking \& Finance: Principles, Instruments \& Operations (CLJ Publication, 2016).

${ }^{20}$ International Narcotics Control Strategy Report, Bureau for International Narcotics and Law Enforcement Affairs, State

${ }^{21}$ Norhashimah Mohd Yasin, "Legal Issues Related to the Shariah Advisory Council in Malaysia," Jurnal Media Hukum 20, no. 1 (2013). 
financing the latest report of Asian Pacific Group (APG) (a regional FATF on) Malaysia was favourable. According to the Mutual Evaluation Report 2015, 'Malaysia's robust policy framework for AML/CFT reflects strong political commitment and well-functioning coordination structures for AML/CFT and combating proliferation financing'. ${ }^{22}$ The Report also noted that significant resources have been allocated by the Malaysian government to achieve the policy objectives, in addition to coordination arrangements that effectively support the implementation of activities to meet these policy objectives. ${ }^{23}$

The negative effect of a spurious allegation like this is overwhelming. Many Muslim charity organisations can no longer genuinely offer aid to the needy. This was scholarly put by Jonathan Benthall in the following words:

"It is significant that even in Saudi-Arabia and Kuwait, with all their wealth derived from oil, private charities are now restricted in sending funds overseas for relief". ${ }^{24}$

However, whether the legal environment in countries where Islamic banks are operational; is more vulnerable to antics of launderers and to abuse by the terrorist groups or financiers as compared to conventional banks, is yet to be clarified and conclusively determined. ${ }^{25}$ In the absence of clear evidence, a mere speculation that in all Muslim countries that operates Islamic banks, the risk of money laundering and terrorism financing (in Islamic finance) is higher due to lax rules therefore seems to be unfounded.

${ }^{22}$ FATF and APG., "2015 AML/CFT Mutual Evaluation Report on Malaysia" (Paris, 2015), http://www.fatf-gafi.org/.

${ }^{23}$ FATF and APG (2015), Anti-Money Laundering and Counter-Terrorist Financing Measures - Malaysia, Fourth Round Mutual Evaluation Report, FATF, Paris and APG, Sydney www.fatfgafi.org/publications/mutualevaluations/documents/mer-malaysia2015.html

${ }^{24}$ Jonathan Benthall, "The Overreaction against Islamic Charities," Isim Review 20 (2007): 2.

${ }^{25}$ Concha Verdugo Yepes, "Compliance with the AML/CFT International Standard: Lessons from a Cross-Country Analysis," IMF Working Papers, $2011,1-75$. 


\section{FOCUS OF THE AML/CFT STANDARDS BEARER}

The Financial Action Task Force against money laundering (FATF) ${ }^{26}$ is a body that is saddled with the responsibility of designing policy, regulations and legislations (as a standard bearer) globally for combating money laundering and other related predicate offences. FATF has always been addressing challenges faced by financial institutions in its usual review program, in order to either update the regulations or the compliance techniques by taking cognizance of various products provided by financial institutions. However, a major drawback to this is that the focus of FATF has always been conventional finance.

There are no rules or provisions to accommodate the special nature of Islamic finance. How many reviews have been dedicated to Islamic banking institutions when compared to the conventional banking institutions? A lot of studies and researches have been dedicated to AML/CFT risks-based assessment on all identifiable AML/CFT vulnerabilities factors in the financial institutions. However, regrettably these researches and studies are mostly based on conventional finance products. A good example that readily comes to mind is the reports of studies by FATF in 2012.

${ }^{26}$ The FATF is an inter-governmental body which sets standards, and develops and promotes policies to combat money laundering and terrorist financing. It currently has 33 members: 31 countries and governments and two international organisations; and more than 20 observers: five FATF-style regional bodies and more than 15 other international organisations or bodies. A list of all members and observers can be found on the The FATF is an inter-governmental body which sets standards, and develops and promotes policies to combat money laundering and terrorist financing. It currently has 33 members: 31 countries and governments and two international organisations; and more than 20 observers: five FATF-style regional bodies and more than 15 other international organisations or bodies. A list of all members and observers can be found on the FATF website at http://www.fatfgafi.org/Members_en.htm. Financial Action Task Force, "The Forty Recommendations," 2003. see also Financial Action Task Force, "Methodology for Assessing Compliance with the FATF 40 Recommendations and the FATF 9 Special Recommendations," Paris, www.Fatf-Gafi.Org,2004. 
The said FATF studies and report was on "Specific Risk Factors in Laundering the Proceeds of Corruption Assistance to Reporting Institutions". ${ }^{27}$ As comprehensive as that study and report was, Islamic banking institutions were not deemed fit to be properly examined. Almost all the case studies referred, cited or reported to buttress the conclusion are essentially those that are specific products of conventional banking institutions.

For instance, the James Ibori's case, Pavel Lazarenko's case on the use of corporate vehicles to hide assets and another 14 cases referred to as case studies in the reports are purely on those instances that are peculiar to conventional banking institutions. ${ }^{28}$ When the identifiable risks contained in the reports are considered, they are seen to be on products that are not associated with Islamic Banking Institutions or any Islamic Finance products. ${ }^{29}$ Thus the reports appears to be rather one sided. Meanwhile FATF Recommendations remains the acceptable standards globally on anti-money laundering (AML) and counter-terrorist financing (CFT) guiding all financial institutions.

Besides the FATF, there are many other internationally recognised bodies involved in the efforts to combat money laundering. One of these bodies is the Basel Committee on Banking Supervision (BCBS). Its recent publication ${ }^{30}$ emphasizes on the identification of the risks assessment and necessary steps to be taken by financial institutions. However, again a critical analysis of the publication will reveal that its focus is essentially on conventional banks.

The Wolfsberg Group ${ }^{31}$ is another international organisation of importance as far as AML/CFT risks are concerned. It too has devoted

27 FATF Publication, "FATF Specific Risks Factors in the Laundering of Proceeds of Corruption," 2012, http:/www.fatf-gafi.org/publications.

${ }^{28}$ Verdugo Yepes, "Compliance with the AML/CFT International Standard: Lessons from a Cross-Country Analysis."

${ }^{29}$ Maruf Adeniyi Nasir, Yazid Mohd bin Kepli and Norhashima Mohd Yasin "Money Laundering: A Paradox of Deterrence Mechanism.," International Journal of Business, Economics and Law 11, no. 3 (2016): 45-55.

${ }^{30}$ In January 2014, the Basel Committee on Banking Supervision (BCBS) issued a document, entitled "Sound Management of Risks related to Money Laundering and Financing of Terrorism" see www.bis.org/publ/bcbs accessed on the 26th December,2016.

${ }^{31}$ The Wolfsberg Group consists of the following financial institutions: Banco Santander, Bank of America, Bank of Tokyo Mitsubishi-UFJ Ltd, Barclays, 
little or no time for the study of potential AML/CFT risks that can arise from Islamic finance. A good example that is likely to back such argument is the recent 'Risks' assessment document released by Wolfsberg Group ${ }^{32}$ that is one of the major stakeholders recognised by FATF on compliance with AML/CFT regulations. As detailed in the said document, it is found to be essentially based on Conventional finance. ${ }^{33}$ For instance, while there are numerous ways to conduct Risk Assessments, the table below shows a diagram of AML/CFT risk assessment method of a conventional/standard. There is also no corresponding AML/CFT risk assessment method for Islamic/standard or for products that are peculiar to Islamic banking institutions.

The Conventional/Standard Risk Assessment Method

\begin{tabular}{|c|c|c|}
\hline Inherent Risk & Control Effectiveness & Residual Risk \\
\hline \multirow{2}{*}{ Clients } & Governance & \multirow{4}{*}{ Strategic Actions } \\
\hline & Policies \& Procedures & \\
\hline \multirow{3}{*}{ Products \& Services } & KYC/Due Diligence & \\
\hline & Other Risk Assessments & \\
\hline & Management Information & \multirow{4}{*}{ Tactical Actions } \\
\hline \multirow{3}{*}{ Countries } & Record Keeping/Retention & \\
\hline & AML Unit & \\
\hline & SARFFlings & \\
\hline \multirow{2}{*}{ Channels } & Monitoring \& Controls & \multirow{4}{*}{ Risk Appetite: } \\
\hline & Controls & \\
\hline \multirow{2}{*}{ Others } & Training & \\
\hline & Independent Testing & \\
\hline
\end{tabular}

Citigroup, Credit Suisse, Deutsche Bank, Goldman Sachs, HSBC, JPMorgan Chase, Société Générale, Standard Chartered and UBS

${ }^{32}$ Ibid.

${ }^{33}$ Wouter H Muller, Christian H Kalin, and John G Goldsworth, Anti-Money Laundering: International Law and Practice (John Wiley \& Sons, 2007). 


\section{Source: Wolfsberg-Risk-Assessment-FAQs-2015}

The above diagram illustrates the most likely expected practice in a conventional financial institution as contained in the Wolfsberg Risks Assessment Document. Each of the items on the diagram is treated in detail with useful suggestions. Moreover, to determine or identify customers that are categorised as Politically Exposed Persons (PEPs) or their beneficial owners, who as specified by FATF are to be classified as high-risk customers ${ }^{34}$, financial institutions or any other reporting entity are required to put in place an appropriate and effective risk management systems. An enhanced Customer Due Diligence (CDD) is equally expected in that circumstance. Therefore, more specific measures are expected that goes beyond the usual CDD. Notable here is the fact that the rules are applicable to all financial institutions and other reporting agencies. ${ }^{35}$

This is to illustrate that while the rules are general in terms of expected compliance to the laid down standard, the likely AML/CFT vulnerable risks must be identified. Regrettably enough, it is only the AML/CFT risks of conventional institutions that have attracted several studies. Presently, there is an avalanche of research publications on various techniques and methods, typologies and trends that are peculiar to the conventional financial sector, unlike its Islamic counterpart. Surprisingly, most of these studies are done or sponsored by international agencies like FATF that are meant for all financial institutions.

It is therefore worrisome that there is no concrete study done by FATF or recognised agencies on risk posed by Islamic banking institutions (IBI) on AML/CFT risks. Islamic banking appears not to have attracted reasonable critical attention ${ }^{36}$ compared to the AML/CFT risks of the conventional banking sector, where several studies have been carried out on the trends and typologies. ${ }^{37}$ Rather than allowing the international standard setters on AML/CFT to come out with risks that

\footnotetext{
${ }^{34}$ FATF recommendation 12.

${ }^{35}$ Francisco Daniel Zepeda Lázarus and AMLCA CFE, "A Risk-Based Framework for Assessing A Compliance Culture," 2015.

${ }^{36}$ Nadim Kyriakos-Saad et al., "Islamic Finance and Anti-Money Laundering and Combating the Financing of Terrorism (AML/CFT)," 2016.

37 http://www.fatf-gafi.org/topics/methodsandtrends/ accessed on $20^{\text {th }}$ November, 2016.
} 
may be associated with Islamic finance, the atmosphere was filled with erroneous impressions about the compliance of Islamic Banking with AML/CFT regulations ${ }^{38}$. This assumption is partly based on a common mistake that anything Islamic is synonymous to terrorism and prone to be lax. This attitude has been described as 'Islamophobia'. ${ }^{39}$ The outcome of which is hatred and discrimination. ${ }^{40}$

\section{REQUIREMENT OF AML/CFT AND ISLAMIC FINANCE INSTITUTIONS}

AML/CFT risks are becoming more prevalent and unfortunately no financial institution is spared from being vulnerable to this menace while its risk to the international flows is observed to be increasingly volatile. Considering the FATF Recommendations, AML/CFT financial supervision is hinged on six basics requirements; an evaluation of those requirements would reveal that there are possibilities of Islamic banking institutions being less vulnerable to AML/CFT risks due to their operational mechanics.

The six requirements include the following;

(1) Identification of customers and their beneficial owners;

(2) More vigilance and diligence on any unusual transactions;

(3) Suspicious Transactions Reporting (STR);

(4) Documentation and proper record of relevant documents;

(5) Cash Transaction Reporting (CTR) once above the threshold; and

(6) Enhanced Due Diligence on PEPs and financial intermediaries.

Incidentally, many countries that operate Islamic banks are confirmed to have complied with all these required AML/CFT compliance indices. Malaysia and the United Kingdom are examples in this category. This is discussed in another segment.

\footnotetext{
${ }^{38}$ Mohd Yazid Zul Kepli, "The Common Mistakes in Combating Terrorism Financing," International Journal of Business, Economics and Law, Vol. 10, Issue 5 (Aug.) 2016.

2016.

${ }^{39}$ Ibid.

${ }^{40}$ Ibid.
} 
Islamic banking is participatory in nature. The transaction is based on a risk sharing formula, in which transactions are driven by strong ethical precepts. Uncertainty is prohibited and partnership with customers is mostly specified in the transactions. These are basic characteristics of Islamic banking institutions that are likely to put them at a vantage position that will enable them to know their customers in and out, compared to conventional institutions where fixed and predetermined returns are relied upon, and where the concern and emphasis are likely to be more on the realisation of the expected returns over and above the integrity and personality of the customers. This is because in a conventional banking institution, the focus in most cases is more on the securities provided.

The participatory mechanism which is built on profit and loss sharing (risks sharing) can facilitate the necessary contacts that are likely to reveal the real identity of customers under Islamic banking. Although, in practice, this might not always happen. This is probably because there are many transactions of Islamic banks that are not based on profit and loss sharing. However, it could be argued that participatory mechanism is embedded in Islamic banking. The way and manner the bank interacts with its customer can be said to be a key factor in the Know Your Customer (KYC) policy and can be the basis for risks assessments. The way and manner in which the bank relates with its customers is therefore a necessary consideration for risks assessment preparation by any financial institutions and the nature of Islamic banking no doubt makes its identification of customers easier.

Moreover, Islamic banks are under obligations to comply with Shariah precepts which abhor dealing in all prohibited items such as pornographic items, alcoholic substances, gambling, weapons of mass destruction, speculation, psychotropic substances, and all other product that are forbidden under the principles of Shariah. Proceeds of crime therefore has no basis to be associated with Islamic banks. In addition, the Islamic system of finance is asset based. The fact that can be deduced from the above is that it is easier to know how funds are being utilised. This is regarded as one of the required best compliance practices.

One would now be wondering where the theory that Islamic banks are more vulnerable to AML/CFT risks came from, and if all the available facts about the nature of Islamic Banks were reasonably considered. Whether such perception is fact or fallacy is evaluated in the succeeding discussion. 


\section{AML AND THE NEGATIVE PERCEPTIONS ON ISLAMIC BANKS}

Many scholars such as Normah, ${ }^{41}$ Sullivan and Hendriks ${ }^{42}$ agreed that that there has been negative perception against Islamic financial institutions. Most of these scholars (based on their studies) have come out with findings that various terror attacks in certain jurisdictions across the world (particularly that of US) had fuel and left some very detrimental global perceptual impacts on the Muslims and Islamic financial institutions globally. For instance, the negative perception of anything Islamic by an average American was found to have increased tremendously after the 2011 terror attack in a study carried out by Sullivan and Hendriks. ${ }^{43}$

According to Normah, this negative perception brought a lot of public scepticism against the Muslims and the religion of Islam. This thought is captioned as follow:

"The terrorist attacks of the United States (US) World Trade Centre on September 11, 2001; Bali bombings in 2002 and 2005; London Bombing in 2005; and the Mumbai bombing in 2008 had left some very detrimental global perception impacts on the Muslims and Islamic financial institutions globally. As most of these attacks were carried out by some militant Islamists, understandably there were a lot of public scepticism against the Muslims and the religion of Islam. In the United States of America (USA) for example, following the attacks on September 11, the US government enacted the USA PATRIOT Act, which is basically designed to prevent the use of the US financial system to help fund terrorism and other crimes. The enactment of the PATRIOT Act 2001 had accelerated the establishment of similar laws globally". ${ }^{44}$

${ }^{41}$ Normah Omar, "Terrorist Financing and Perceeptions on Islamic Financial Institutions," 2010.

42 John L Sullivan and Henriët Hendriks, "Public Support for Civil Liberties Pre-and Post-9/11," Annual Review of Law and Social Science 5 (2009): $375-91$.

${ }^{43}$ Ibid.

44 Omar, "Terrorist Financing and Perceeptions on Islamic Financial Institutions." 
Based on earlier studies as identified above, the allegation of laxity in the control of money laundering against Islamic Banks as well as the views that there are possibilities of their being more vulnerable to AML/CFT risks are most likely to be influenced by the post American September $9^{\text {th }}, 2011$ experience. ${ }^{45}$ This position is also in tandem with findings of an earlier study conducted by the Cornell University in 2004. The findings established the fact that the terror attack experienced by the Americans during the September attack had created considerable public fears in the psyche of an average Americans towards terrorism and almost half of those polled proposed that the US government should curtail civil liberties for Muslim Americans. ${ }^{46}$

It is a notable fact that ever since then, the study of money laundering and terrorist financing risk in Islamic finance has attracted relatively little interest. ${ }^{47}$ Thus, the allegation of laxity against Islamic banks is still significantly based on assumption that has not been empirically proved. What could however be substantiated is the fact that the US and its close allies have a phobia for anything Islamic which is most likely to affect its objectivity in the evaluation of Islamic issues.

This is evident in a recent research conducted by Pew Research Centre. The outcome of the results placed Islam to the extreme bottom of the scale, getting an average rating of 40 out of 100 . Jews with $(63 \%)$ obtained the most positive feeling, closely followed by the Catholics with (62\%) and Evangelical Christians (61\%). ${ }^{48}$ This outcome can therefore be said to depict the phobia which average Americans have for Islam and unfortunately such hatred appears to be reflected on anything that can be identified with Islam.

The issue of AML/CFT compliance is presently a problem in most countries of the world. While there is evidence that a lot of countries have put in place sufficient legislation and regulations to combat money laundering and financing terrorism in line with the international standards

${ }^{45}$ Norhashimah Mohd Yasin, "The Annotated Statutes of Malaysia: Anti-Money Laundering and Terrorist Financing Act" (Kuala Lumpur: LexisNexis, 2009).

${ }^{46}$ Omar, "Terrorist Financing and Perceeptions on Islamic Financial Institutions."

${ }^{47}$ IMF Working Paper, Islamic Finance and Anti Money Laundering and Combating the Financing of Terrorism (AML/CFT), WP/15/XX by Nadim Kyriakos-Saad et all.

${ }^{48}$ Washington Post 1 August 2016 
as contained in the FATF Forty Recommendations, the same cannot be said of the actual implementation of the said legislations and regulations. The enforcement of such legislation is still far from attaining a desirable level of compliance. The FATF findings corroborate this position. In a recent FATF study, the outcome reveals that the rate of compliance with the standard in many countries of the world is still very low. It is worthy of note that many countries (irrespective of their adopted financial system) remain either in the FATF list of AML/CFT blacklisted countries or as non -cooperating nations for deficiencies in certain core and key compliance indices (requirements). ${ }^{49}$

For instance, countries such Ecuador, Ethiopia, Kenya, Myanmar, Vietnam, Tanzania, Indonesia, Pakistan, Syria and many others were recently listed among jurisdictions with strategic AML/CFT deficiencies that have not made "sufficient progress or have not committed to any action plan". FATF equally admitted recently in its public statement that many jurisdictions have strategic deficiencies that pose risk to the international financial system and many jurisdictions are "with strategic AML/CFT deficiencies and have not made sufficient progress in addressing the deficiencies or have not committed to an action plan". ${ }^{50}$

It is interesting to note that a cursory look at these lists reveal that it comprised jurisdictions which cut across all financial systems. This is a clear attestation that AML/CFT is not restricted to a financial system or jurisdiction. Moreover, it cannot be said to be not influenced negatively by a particular religious belief. The glaring fact is that no financial institution is spared from being vulnerable. Attaching AML/CFT's noncompliance; specifically, with Islamic banks would therefore appear to be a one sided and spurious allegation. A reasonable step that is expected would be to identify general and specific money laundering risks pertaining to all financial institutions without distinction. This is vital for compliance because these identifiable and conceivable risks can be

${ }^{49}$ Financial Action Task Force, "The FATF Recommendations: International Standards on Combating Money Laundering and the Financing of Terrorism \& Proliferation" (Paris: FATF, 2015). See also “International Standards on Combating Money Laundering and the Financing of Terrorism \& Proliferation," accessed January 19, 2016, http://www.fatfgafi.org/media/fatf/documents/recommendations/pdfs/FATF_Recommendatio ns.pdf.

${ }^{50}$ Ibid. 
effectively reflected in the financial institutions AML compliance programme.

Similarly, an International Monetary Fund (IMF) working paper recently published, contains the outcome of a research that focused on compliance with AML/CFT. 142 countries were assessed from 2004 to April 2011, where the findings revealed that it is very difficult to see any country with full compliance. When those ranked to be very close to full compliance (based on the tested principle) were scored, only $12.9 \%$ fell into this category. 11 countries are said to be largely compliant which comprised only $26 \% .{ }^{51}$ Compliance with AML/CFT is therefore - more or less a general problem.

However, if available records of compliance in Malaysia, Brunei, the UK and many other countries are considered, drawing a conclusion that Islamic banks is faring better compared to conventional banks would be easily drawn. the United Kingdom (UK)'s compliance record in the recent past is a good example. ${ }^{52}$ For instance, unlike conventional institutions in the UK, none of the Islamic banks or other Islamic financial institutions is found culpable or sanctioned for non-compliance with AML related issues. This UK example is significant because, the country is one of the highly rated countries in term of compliance with AML/CFT measures. The FATF Mutual Evaluation Reports (MERs) also shows that the UK's AML/CFT comply with all the require compliance indices. The MER's conclusion on the UK compliance measures are satisfactorily. It stated as follows:

Given the progress on R.5, the UK has reached a satisfactory level of compliance with all core Recommendations and key Recommendation... ${ }^{53}$

${ }^{51}$ Verdugo Yepes, "Compliance with the AML/CFT International Standard: Lessons from a Cross-Country Analysis",( IMF working paper, 2011).

${ }^{52}$ Norhashimah Mohd Yasin, "Regulation of Islamic Banks and Allegations of Lax Control of Money-Laundering," Journal of Islamic Law Review 4 (2008).

${ }^{53}$ Financial Action Task Force, "Third Mutual Evaluation Report on AntiMoney Laundering and Combating the Financing of Terrorism: United Kingdom of Great Britain and Northern Ireland," Available at: Www. FatfGafi. org/dataoecd/55/29/39064399. Pdf (Accessed 29 June 2007), 2007, 275. 
The record of the UK AML/CFT regulatory agency, Financial Conduct Authority (FCA) in the last one decade shows clearly that Islamic banks are more complying with the AML/CFT measures. ${ }^{54}$ This position is inferred from the record of financial institutions that were penalised for non-compliance in the last one decade. ${ }^{55}$

Unlike Islamic banks, many conventional banks have been sanctioned in the UK for non-compliance with AML Measures. While individuals were also fined along with their firms none is yet to be recorded against Islamic banks or their staff. It is on record that The UK FCA fined Guillaume Adolph of Deutsche Bank $£ 180,000$ (\$250,000) and permanently banned him from the financial services industry. While a $£ 163.1$ million fine was issued against a conventional bank (Deutsche Bank) on 30 January 2017 for failures in AML controls. ${ }^{56}$

The table below shows the record of highest fines recorded by the UK, FCA in the recent reports. It is interesting to note that none of the Islamic institutions is inclusive.

Table 1

AML/CFT Fines in the UK

\begin{tabular}{|l|c|c|l|}
\hline $\begin{array}{l}\text { FINANCIAL } \\
\text { INSTITUTION }\end{array}$ & YEAR & FINE & $\begin{array}{l}\text { NATURE OF } \\
\text { OFFENCE }\end{array}$ \\
\hline $\begin{array}{l}\text { Sonali Bank (UK) } \\
\text { Limited }\end{array}$ & 2016 & $£ 3.25$ million & $\begin{array}{l}\text { failures in anti- } \\
\text { money } \\
\text { laundering } \\
\text { (AML) controls }\end{array}$ \\
\hline $\begin{array}{l}\text { Aviva Pension } \\
\text { Trustees UK } \\
\text { Limited and Aviva } \\
\text { Wrap UK }\end{array}$ & 2016 & $£ 8.2$ million & $\begin{array}{l}\text { insufficient } \\
\text { oversight of an } \\
\text { outsourcer in } \\
\text { relation to client } \\
\text { money rules. }\end{array}$ \\
\hline Deutsche Bank & 2017 & $£ 163.1$ & failures in anti- \\
\hline
\end{tabular}

${ }^{54}$ Kim-Kwang Raymond Choo, "Designated Non-Financial Businesses and Professionals: A Review and Analysis of Recent Financial Action Task Force on Money Laundering Mutual Evaluation Reports," Security Journal 27, no. 1 (2014), doi:10.1057/sj.2012.9.

55 Erin B. McHugh, "Trends in Regulatory Enforcement in UK Financial Markets 2017/18 Mid-Year Report” (London, 2018), .

${ }^{56}$ Ibid. 


\begin{tabular}{|l|l|l|l|}
\hline & & million & $\begin{array}{l}\text { money } \\
\text { laundering } \\
\text { (AML) controls }\end{array}$ \\
\hline $\begin{array}{l}\text { Tesco shares and } \\
\text { bonds }\end{array}$ & 2017 & $\begin{array}{l}£ 129.0 \\
\text { million }\end{array}$ & $\begin{array}{l}\text { financial crime } \\
\text { and AML }\end{array}$ \\
\hline
\end{tabular}

Source: Adapted from NERA Mid-year Reports 2017/20

Table 2

10 Top AML/CFT Fines against Firms, 1st April 2002 to Present in the UK

\begin{tabular}{|l|l|l|l|}
\hline \multicolumn{1}{|c|}{ Firm } & $\begin{array}{l}\text { Financial } \\
\text { Year }\end{array}$ & $\begin{array}{l}\text { Total Fine } \\
(\mathfrak{\xi})\end{array}$ & $\begin{array}{l}\text { Category of } \\
\text { Misconduct }\end{array}$ \\
\hline Barclays Bank plc & $2015 / 2016$ & 284,432 & $\begin{array}{l}\text { Failure to prevent } \\
\text { misconduct }\end{array}$ \\
\hline UBS AG & $2014 / 15$ & 233,814 & $\begin{array}{l}\text { Failure to prevent } \\
\text { misconduct }\end{array}$ \\
\hline $\begin{array}{l}\text { Deutsche Bank } \\
\text { AG }\end{array}$ & $2015 / 16$ & 226,800 & $\begin{array}{l}\text { Market } \\
\text { Manipulation } \\
\text { (Interbank Rate) }\end{array}$ \\
\hline Citibank N.A. & $2014 / 15$ & 225,575 & $\begin{array}{l}\text { Failure to prevent } \\
\text { misconduct (FX) }\end{array}$ \\
\hline $\begin{array}{l}\text { J.P. Morgan Chase } \\
\text { Bank N.A }\end{array}$ & $1014 / 15$ & 222,166 & $\begin{array}{l}\text { Failure to prevent } \\
\text { misconduct (FX) }\end{array}$ \\
\hline $\begin{array}{l}\text { Royal Bank of } \\
\text { Scotland plc }\end{array}$ & $2014 / 15$ & 217,000 & $\begin{array}{l}\text { Failure to prevent } \\
\text { misconduct (FX) }\end{array}$ \\
\hline HSBC Bank plc & $2014 / 15$ & 216,363 & $\begin{array}{l}\text { Failure to prevent } \\
\text { misconduct (FX) }\end{array}$ \\
\hline $\begin{array}{l}\text { Deutsche Bank } \\
\text { AG }\end{array}$ & $2016 / 17$ & 163,076 & $\begin{array}{l}\text { Inadequate Security } \\
\text { \& Safeguards }\end{array}$ \\
\hline UBS AG & $2012 / 13$ & 160,000 & $\begin{array}{l}\text { Market } \\
\text { Manipulation } \\
\text { (Interbank Rate) }\end{array}$ \\
\hline $\begin{array}{l}\text { J.P. Morgan Chase } \\
\text { Bank N. A }\end{array}$ & $2013 / 14$ & 137,610 & $\begin{array}{l}\text { Transaction } \\
\text { Reporting, Record- } \\
\text { Keeping, \& Pricing } \\
\text { Failures }\end{array}$ \\
\hline
\end{tabular}


Source: NERA Mid-year Reports 2017/2018, page 7

In the same vein, Malaysia was assessed to have substantially complied with FATF AML/CFT measures. And based on its positive records, the country has been admitted as member of FATF in 2017. According to FATF, in the latest MER reports:

"Malaysia has a strong legal and regulatory framework for preventative measures, which demonstrated a high degree of technical compliance with the FATF standards. Interagency coordination and policy frameworks, BNM's supervision, the FIU (FIED) and the Special Taskforce achieve significant outcomes and are the key strengthens within Malaysia's AML/CFT system" ${ }^{17}$

This assessment is quite important considering the position of Malaysia as a global leader in Islamic finance. Therefore, evidence of compliance with the international standard by the supervisory agency that control and monitors AML/CFT compliance of Islamic banks in Malaysia shows that Islamic banks are complying with AML/CFT measures. Moreover, in the analysis of Know Your Countries Reports on Malaysia, the regulatory and enforcement of AML/CFT measures were adjudged in the following manner:

"Malaysia has taken strong regulatory and enforcement measures to
control the MSB sectors (remitters and money changers) in response to
significant risks, but unauthorized illicit MSBs continue to pose a
significant vulnerability, including with respect to TF. Malaysia is a net
outbound remitter of funds, with a large presence of migrant workers
both legal and illegal. Strengthened controls, enforcement and other
supervisory measures are resulting in significant increases in formal
channels for remittance which should mitigate the level of risk posed
by this sector."

The fact that Malaysia is not listed among the countries with AML deficiencies despite her status as hub for Islamic finances is equally significant. This is a plus in term of AML/CFT control and supervisory mechanisms, particularly, as applicable to Islamic banks. The implication

57 FATF Publication, "Malaysia AML/Know Your Country” (Paris, 2016), https://www.knowyourcountry.com/malaysia. Emphasis added. 
of this is that, allegation of lax control against Islamic banks without exception could be concluded to have been overgeneralised as earlier stated. Malaysia's MER reports (of the FATF) provides a good evidence in that regard. ${ }^{58}$

It is also of significant to note that, Malaysia has not been sanctioned by FATF or any other known international bodies. This attests to its strong AML/CFT regime. Concerning the overall level of compliance and effectiveness of AML/CFT in Malaysia, the MER provides as follows:

\begin{abstract}
"Malaysia has a significant Islamic Finance sector involving banks, takaful (Islamic insurance) and other intermediaries which are subject to the same AML/CFT legal and regulatory regime as conventional and Islamic Finance institutions. Supervisors are of the view that, based on their supervisory experience, there are no material differences in risks when compared to conventional FIs (for example Islamic banks and non-Islamic bank are all rated as high-risk sectors). The NRA and other assessments considered ML and TF risks for all sectors of FIs and did not separately assess ML/TF risk and vulnerabilities in the Islamic Finance verse the conventional Finance sector as it did, for example, for the domestic and offshore sector". ${ }^{59}$
\end{abstract}

\title{
CONCLUSION
}

There is no doubt that AML/CFT is a global problem, which requires combating through a strong cooperation of all the stakeholders and countries. Its risk to the international trade flow exchange rate volatility has become even more intense and foreign direct investments are adversely affected. It is obvious that no financial institution is immune to being used by the launderer. ${ }^{60} \mathrm{In}$ these circumstances, the adoption of a more inclusive approach ought to be adopted. To this end, it is the contention of this article that, attention should be focused on the AML/CFT risks of all the financial institutions irrespective of their nomenclature. The international standard bearer organisations should equally focus on the study of Islamic financial products as they had been doing in conventional finance in order to design AML/CFT regimes that

\footnotetext{
${ }^{58}$ Ibid.

${ }^{59}$ APG., "2015 AML/CFT Mutual Evaluation Report on Malaysia.”

${ }^{60}$ Ibid.
} 
will possibly checkmate any potential risks. The earlier this is be done, the better the assurance of enabling the international regulatory agencies to achieve global economic and financial stability. 